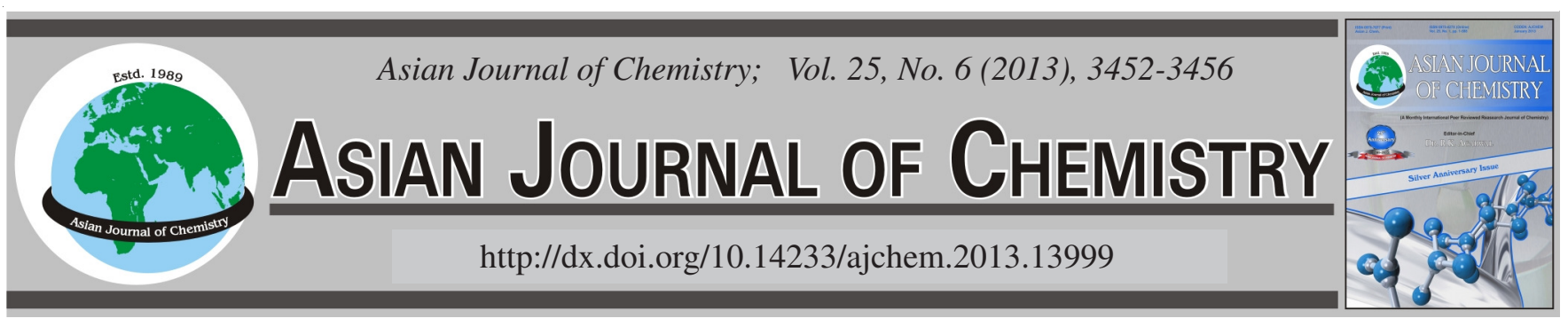

\title{
Automatic Biamperometric Titration of Copper(II) by Iodide in Some Non-Aqueous Media
}

\author{
Abdul Aziz Ramadan* ${ }^{*}$, Hasna Mandil and Nour Ghazal
}

Department of Chemistry, Faculty of Sciences, Aleppo University, Aleppo, Syria

*Corresponding author: Fax: +963 21 2633136; E-mail:dramadan@ scs-net.org

(Received: 30 April 2012;

Accepted: 24 December 2012)

AJC-12613

\begin{abstract}
Automatic biamperometric titration of copper (II) by iodide in non-aqueous media (methanol, ethanol, propanol, butanol and acetonitrile) was applied. In methanol no quantify acceptable curves appeared. In ethanol two end-points were observed, the first one according to the equation: $2 \mathrm{Cu}^{2+}+4 \mathrm{I}^{-} \rightarrow 2 \mathrm{CuI} \downarrow+\mathrm{I}_{2}$ (I), while, the second-according to the following equation: $\mathrm{I}_{2}+\mathrm{I}^{-} \rightarrow \mathrm{I}_{3}^{-}$(II). In propanol and butanol two end-points were observed, the first one according to the equation: $2 \mathrm{Cu}^{2+}+2 \mathrm{I}^{-} \rightarrow 2 \mathrm{Cu}^{+}+\mathrm{I}_{2}$ (III), the second-according to the following equation: $\mathrm{Cu}^{+}+\mathrm{I}^{-} \rightarrow \mathrm{CuI} \downarrow$ (IV). Finally in acetonitrile two end-points were observed, the first one according to the equation (III) and the second according to the equation (II). The proposed method was successfully applied, for the first time, for the determination of $4 \times 10^{-5} \mathrm{~mol}$ $\mathrm{L}^{-1}$ copper (II) with RSD not more than $4.2 \%$. The electrochemical reversibility of $\mathrm{Cu}^{2+} / \mathrm{Cu}^{+}$and $\mathrm{I}_{2} / \mathrm{I}_{3}{ }^{-}$couples and irreversibility of $\mathrm{Cu}^{+} /$ $\mathrm{Cu}$ is indicated by biamperometry. The behaviour of $\mathrm{Cu}^{2+}, \mathrm{Cu}^{+}, \mathrm{CuI}, \mathrm{I}_{2}$ and $\mathrm{I}_{3}^{-}$has been compared. A comparison with solvents has also been made.
\end{abstract}

Key Words: Biamperometric titration, Copper(II), Iodide, Acetonitrile.

\section{INTRODUCTION}

The amperometric detection with two polarized indicating electrodes (also named as biamperometic detection) is based on the measurement and the intensity of current passing through the two identical, usually inert, electrodes, to which a small potential difference from few tens to few hundreds milli volts was applied. The current flowing in the detection cell is observed only, when solution contacting the electrodes contains two forms of reversible redox couple, it means such one for which at the same potential the oxidation of the reduced form or the reduction of oxidized form can occur. This behaviour is observed for such couples as $\mathrm{Br}_{2} / \mathrm{Br}^{-} ; \mathrm{I}_{2} / \mathrm{I}^{-} ; \mathrm{Fe}^{3+}$ / $\mathrm{Fe}^{2+} ; \mathrm{Ce}^{4+} / \mathrm{Ce}^{3+} ; \mathrm{Ag}^{+} / \mathrm{Ag} ; \mathrm{AgI} / \mathrm{Ag}, \mathrm{I}^{-} ; \mathrm{AgBr} / \mathrm{Ag}, \mathrm{Br}^{-} ; \mathrm{AgCl} /$ $\mathrm{Ag}, \mathrm{Cl}^{-}$; quinine/hydroquinine; $\mathrm{Cu}^{2+} / \mathrm{Cu}^{+}$(in some nonaqueous media), etc..$^{1-3}$.

In biamperometric detection, in the presence of an excess of one form of reversible redox couple, the magnitude of the current measured is linearly proportional to the concentration of the second form in the solution as long as concentration over potential is not involved. When the polarizing potential difference applied to the electrodes is increased, an extension of the linear range of response is observed, however, it is associated with possible interference for other redox species present in solution. When the system detected in the solution is irreversible, the oxidation and reduction processes have activation potentials much larger, even up to $1 \mathrm{~V}$. Such a large polarizing potential difference is also applied in biamperometric detection carried out in non-aqueous solvents ${ }^{4,5}$.

Potentiometric titrations of copper(II) in aqueous media were applied $^{6-10}$. In these case get a one end-point only. While in non-aqueous media some titration of $\mathrm{Cu}$ (II) were used as the potentiometric with $\mathrm{Pt}$ electrode ${ }^{11,12}, \mathrm{Cu}$ elecerode ${ }^{13}$ and ionselective elecerode ${ }^{14}$, conductometric and high frequency ${ }^{15}$; where have received some end-points as the following equations:

$$
\begin{gathered}
2 \mathrm{Cu}^{2+}+2 \mathrm{I}^{-} \rightarrow 2 \mathrm{Cu}^{+}+\mathrm{I}_{2} \\
\mathrm{Cu}^{+}+\mathrm{I}^{-} \rightarrow \mathrm{CuI} \downarrow \\
\mathrm{I}_{2}+\mathrm{I}^{-} \rightarrow \mathrm{I}_{3}^{-} \\
\mathrm{CuI} \downarrow+\mathrm{I}^{-} \rightarrow \mathrm{CuI}_{2}^{-} \\
\mathrm{CuI}_{2}^{-}+2 \mathrm{I}^{-} \rightarrow \mathrm{CuI}_{4}{ }^{3-}
\end{gathered}
$$

The reactions(1-3) get in alcohols, acetonitrile and acetone ${ }^{12-20}$, while the reactions (4 and 5) get in acetone only ${ }^{13,14}$.

In the present measurements, the biamperometric titration of copper(II) by iodide in alcohols and acetonitrile using Pt (two wire) indicator electrode was carried out.

\section{EXPERIMENTAL}

An automatic potentiometer and biamperometre (702 SM Titrino, Metrohm), automatic burette (806 Exchange Unit, Metrohm), indicator electrode (two polarized wire indicating electrodes) type $\operatorname{Pt}(6.0338 .100)$, Metrohm, magnetic stirrer (728 stirrer, metrohm), sensitive balance $(0.01 \mathrm{mg}$, sartorius2474). The dilute pipette model DIP-1 (Shimadzu), having $100 \mathrm{~mL}$ sample syringe and five continuously adjustable pipettes 
covering a volume range from 20 to $5000 \mu \mathrm{L}$ (model Piptman P. Gilson) were used. A ultrasonic process or model POWERSONIC 405 was used to sonicate the sample solutions.

Solutions preparation: All solutions are prepared with methanol, ethanol, propanol, butanol and acetonitrile (extra pure, Merck) with analytical-reagent grade chemicals as the following: $0.01 \mathrm{M} \mathrm{Cu}\left(\mathrm{ClO}_{4}\right)_{2} \cdot 6 \mathrm{H}_{2} \mathrm{O}$ (pure, Fluka ChemikaSwitzerland) was prepared by dissolving of $0.37053 \mathrm{~g}$ in solvent, then transferred into volumetric flask volume of 100 $\mathrm{mL}$ and finally complete the volume to $100 \mathrm{~mL}$ using same solution. 0.1 M KI was prepared by dissolving of $1.660 \mathrm{~g}$ in $1.0 \mathrm{~mL}$ deionized water, added to $60 \mathrm{~mL}$ of solvent, then transferred into volumetric flask volume of $100 \mathrm{~mL}$ and the final volume was completed to $100 \mathrm{~mL}$ using same solvent. All dilutions of the solutions were made with studied solvent.

The appropriate volume of the standard solution of $\mathrm{Cu}$ (II) is putting into volumetric flask volume of $10 \mathrm{~mL}$, added studied solvent until the volume $10 \mathrm{~mL}$, transferred solution to analytical cell and then titrated by iodide.

\section{RESULTS AND DISCUSSION}

Biamperometric titrations of $\mathrm{Cu}^{2+}$ by iodide in some nonaqueous media (methanol, ethanol, propanol, butanol and acetonitrile) were studied as the follows:

In methanol: Biamperometric titrations of $\mathrm{Cu}^{2+}$ by iodide in methanol did not appear quantify acceptable curves.

In ethanol: Two end-points were observed, Fig. 1, the first one according the equation:

$$
2 \mathrm{Cu}^{2+}+4 \mathrm{I}^{-} \rightarrow 2 \mathrm{CuI} \downarrow+\mathrm{I}_{2}
$$

and the second end-point according to the eqn. (3). Fig. 1 shows that, for titration $10 \mathrm{~mL} \mathrm{Cu}^{2+}\left(1 \times 10^{-3} \mathrm{~mol} \mathrm{~L}^{-1}\right)$, which contents $10 \mu \mathrm{mol}$ of $\mathrm{Cu}^{2+}$, gets the following: the first end-point according to titrating $10 \mu \mathrm{mol}$ of $\mathrm{Cu}$ (II) with $20 \mu \mathrm{mol}$ of added iodide to form $10 \mu \mathrm{mol}$ of low solubility salt $\mathrm{CuI}$ and $5 \mu \mathrm{mol}$ of iodine $\left(\mathrm{I}_{2}\right)$. The second end-point according to titration of formed $\mathrm{I}_{2}(5 \mu \mathrm{mol})$ with $5 \mu \mathrm{mol}$ of iodide to form $5 \mu \mathrm{mol}$ of complex $\mathrm{I}_{3}^{-}$.

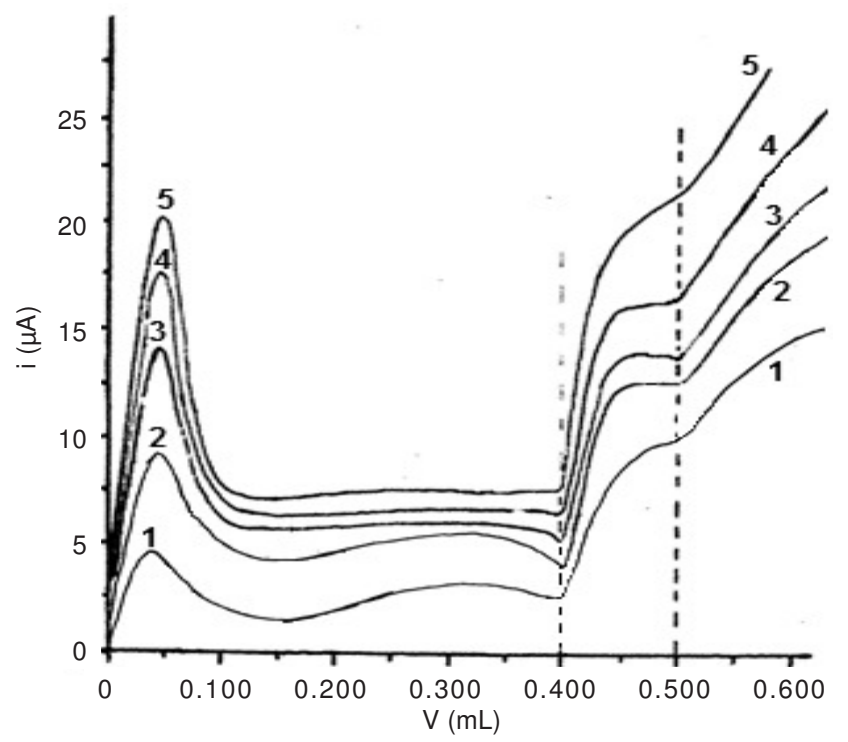

Fig. 1. Biamperometric titration of $10 \mathrm{~mL} \mathrm{Cu}(\mathrm{II}) 1 \times 10^{-3} \mathrm{~mol} \mathrm{~L}^{-1}$ by iodide $0.05 \mathrm{~mol} \mathrm{~L}^{-1}$ in ethanol at different volume $\Delta \mathrm{E}: 1-50 \mathrm{mV}, 2-100$ $\mathrm{mV}, 3-150 \mathrm{mV}, 4-200 \mathrm{mV}, 5-300 \mathrm{mV}$ (Pt electrode)
In propanol: Two end-points were observed, Fig. 2, the first one according the eqn. 1 and the second end-point according to the eqn. 2 . In this case did not show the endpoint titration of $\mathrm{I}_{2}$ by iodide according the eqn. 3. Fig. 2 shows that, for titration $10 \mathrm{~mL} \mathrm{Cu}^{2+}\left(1 \times 10^{-3} \mathrm{~mol} \mathrm{~L}^{-1}\right)$ which contents $10 \mu \mathrm{mol}$ of $\mathrm{Cu}^{2+}$, gets the following: the first end-point according to titrating $10 \mu \mathrm{mol}$ of $\mathrm{Cu}(\mathrm{II})$ with $10 \mu \mathrm{mol}$ of added iodide to form $10 \mu \mathrm{mol}$ of $\mathrm{Cu}^{+}$and $5 \mu \mathrm{mol}$ of iodine $\left(\mathrm{I}_{2}\right)$. The second end-point according to titration of formation $\mathrm{Cu}^{+}(10$ $\mu \mathrm{mol}$ ) with $10 \mu \mathrm{mol}$ of iodide to form $10 \mu \mathrm{mol}$ of low solubility salt CuI.

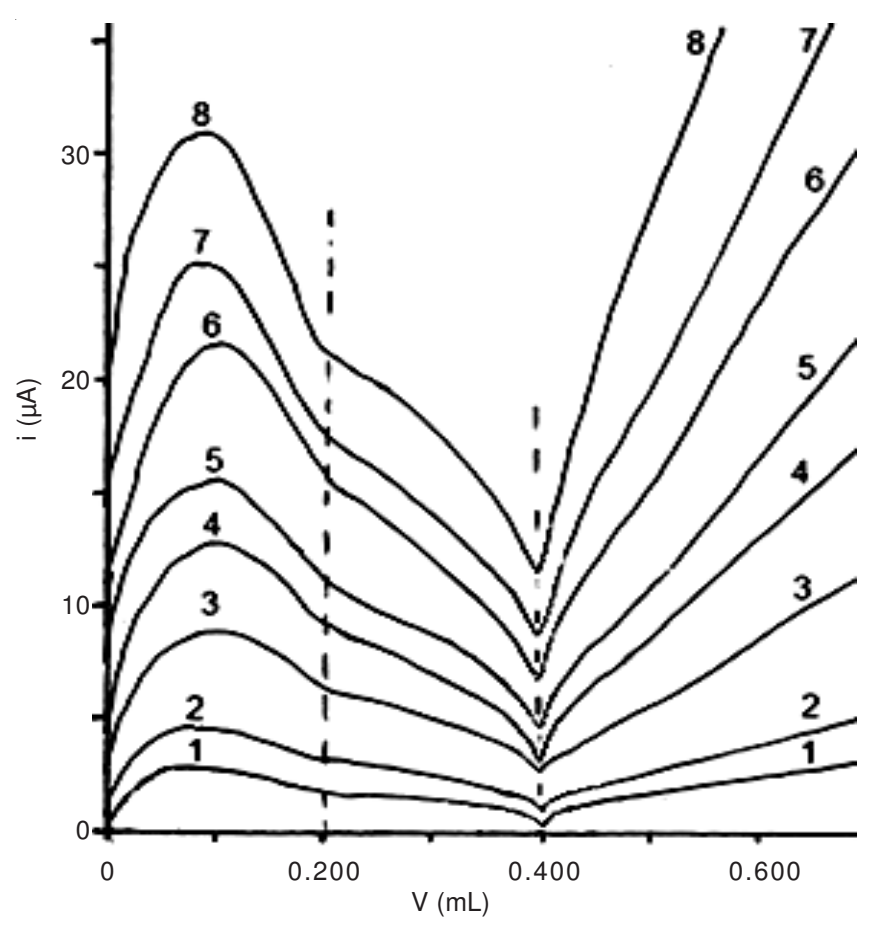

Fig. 2. Biamperometric titration of $10 \mathrm{~mL} \mathrm{Cu}(\mathrm{II}) 1 \times 10^{-3} \mathrm{~mol} \mathrm{~L}^{-1}$ by iodide $0.05 \mathrm{~mol} \mathrm{~L}^{-1}$ in propanol at different volume $\Delta \mathrm{E}: 1-50 \mathrm{mV}, 2-100$ $\mathrm{mV}$, 3- $200 \mathrm{mV}$, 4- $300 \mathrm{mV}, 5-400 \mathrm{mV}$, 6- $500 \mathrm{mV}, 7-600 \mathrm{mV}$ and 8- $800 \mathrm{mV}$ (Pt electrode)

In butanol: Two end-points were observed (Fig. 3, the first one according the eqn. (1) and the second end-point according to the eqn. (2). In this case did not show the endpoint titration of $I_{2}$ by iodide according the eqn. (3). Fig. 3 shows that, the titration in this solvent is similar to the titration in the previous solvent (propanol), but more pronounced.

In acetonitrile: Two end-points were observed (Fig. 4), the first one according the eqn. (1) and the second end-point according to the eqn. (3). In this case the sediment $\mathrm{CuI}$ is not formed. Fig. 4 shows that for titration $10 \mathrm{~mL} \mathrm{Cu}^{2+}\left(1 \times 10^{-3} \mathrm{~mol}\right.$ $\mathrm{L}^{-1}$ ), which contents $10 \mu \mathrm{mol}$ of $\mathrm{Cu}^{2+}$, gets the following: the first end-point according to titrating $10 \mu \mathrm{mol}$ of $\mathrm{Cu}$ (II) with $10 \mu \mathrm{mol}$ of added iodide to form $10 \mu \mathrm{mol}$ of $\mathrm{Cu}^{+}$and $5 \mu \mathrm{mol}$ of iodine $\left(\mathrm{I}_{2}\right)$. The second end-point according to titration of formed iodine $(5 \mu \mathrm{mol})$ with $5 \mu \mathrm{mol}$ of iodide to form $5 \mu \mathrm{mol}$ of complex $\mathrm{I}_{3}^{-}$.

The optimum parameters established for automatic biamperometric titration of copper(II) by iodide in non-aqueous media (methanol, ethanol, propanol, butanol and acetonitrile) using Pt (two wire) indicator electrode were included in Table-1. 


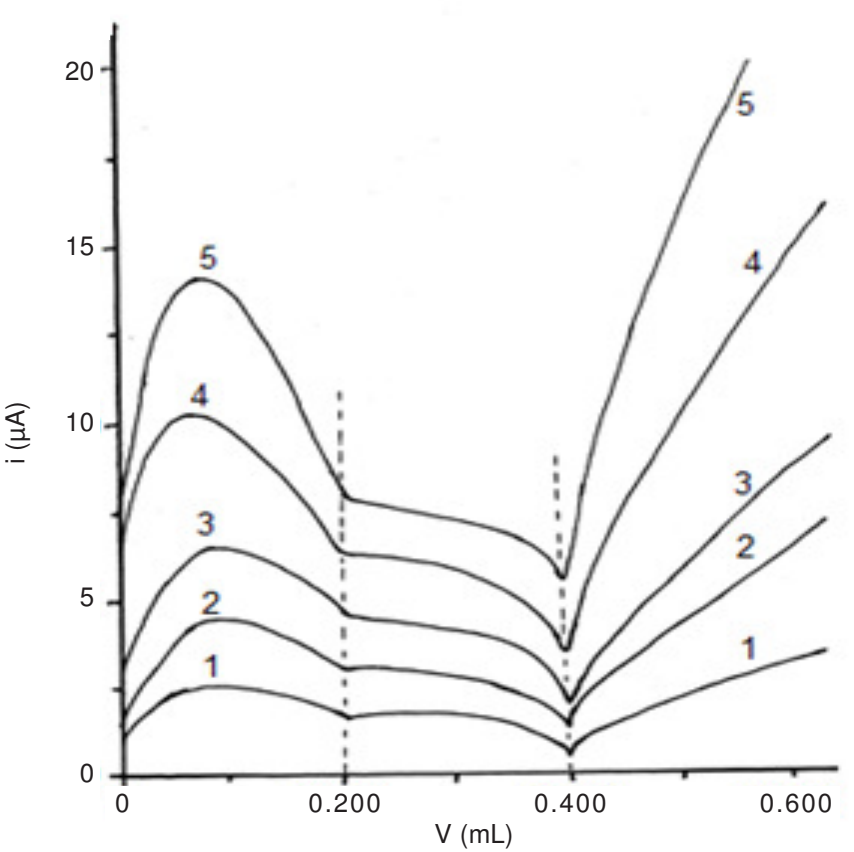

Fig. 3. Biamperometric titration of $10 \mathrm{~mL} \mathrm{Cu}(\mathrm{II}) 1 \times 10^{-3} \mathrm{~mol} \mathrm{~L}^{-1}$ by iodide $0.05 \mathrm{~mol} \mathrm{~L}^{-1}$; in butanol at different volume $\Delta \mathrm{E}: 1-100 \mathrm{mV}, 2-200$ $\mathrm{mV}, 3-300 \mathrm{mV}$, 4- $500 \mathrm{mV}$ and 5- $600 \mathrm{mV}$ (Pt electrode)

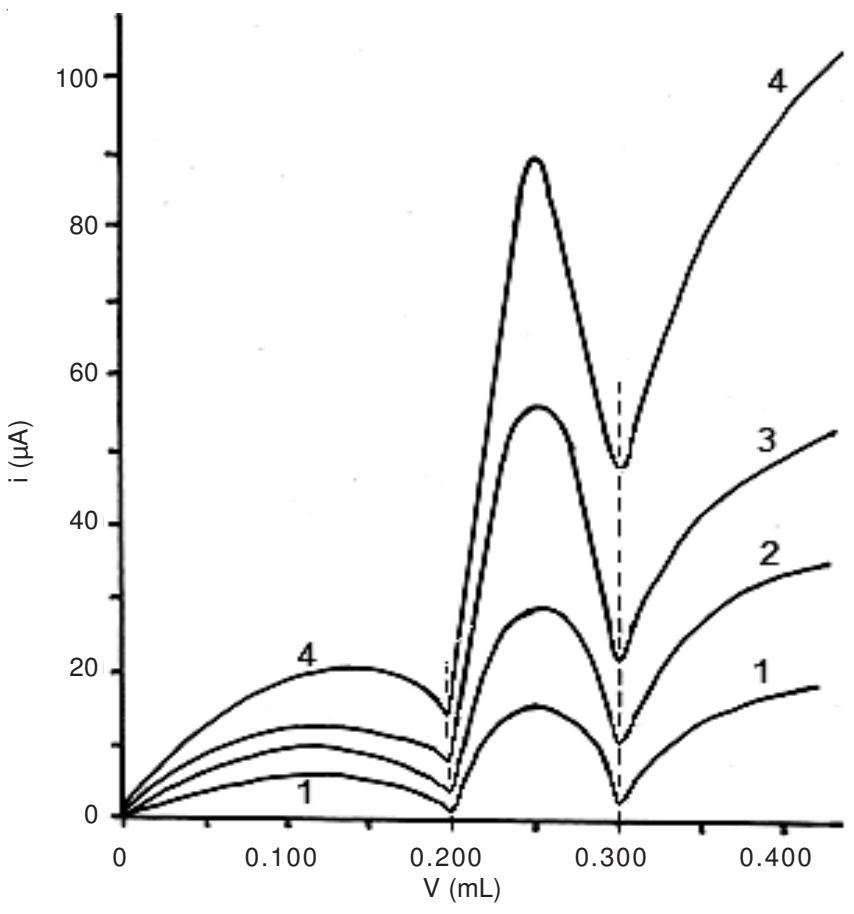

Fig. 4. Biamperometric titration of $10 \mathrm{~mL} \mathrm{Cu}(\mathrm{II}) 1 \times 10^{-3} \mathrm{~mol} \mathrm{~L}^{-1}$ by iodide $0.05 \mathrm{~mol} \mathrm{~L}^{-1}$ in acetonitrile at different volume $\Delta \mathrm{E}: 1-50 \mathrm{mV}, 2$ $100 \mathrm{mV}, 3-200 \mathrm{mV}, 4-400 \mathrm{mV}$ (Pt electrode)

It is worth mentioning here that the titration of $\mathrm{Cu}^{2+}$ by iodide in acetonitrile is the best because of the great stability of the complex $\mathrm{I}_{3}{ }^{-}$; where the formation constant $\left(\mathrm{K}_{\mathrm{f}}\right)$ of $\mathrm{I}_{3}{ }^{-}$in acetonitrile a very high compared with other studied solvents ${ }^{21-24}$ $\left(\mathrm{K}_{\mathrm{f}} \approx 6 \times 10^{6}\right.$ in acetonitrile and 2 to $9 \times 10^{4}$ in alcohols). The redox couple $\mathrm{Cu}^{2+} / \mathrm{Cu}^{+}$in alcohols much high reversible compared with the redox couple $\mathrm{I}_{2} / \mathrm{I}_{3}{ }^{-}$, while the exact opposite of acetonitrile. Biamperometric curves in Figs. 1-4 by using
$\mathrm{Pt}$ (two wire) indicated electrode showed that the redox couples $\mathrm{Cu}^{2+} / \mathrm{Cu}^{+}$and $\mathrm{I}_{2} / \mathrm{I}_{3}{ }^{-}$are reversible and the redox couple $\mathrm{Cu}^{+} / \mathrm{Cu}$ is irreversible. The saturated diffusion constant $\mathrm{K}=\mathrm{i}_{\mathrm{d}} / \mathrm{C}$; where: $\mathrm{i}_{\mathrm{d}}$ : saturated diffusion current and $\mathrm{C}$ concentration, $\mathrm{mol} \mathrm{L}^{-1}$, decreases as the follows: in acetonitrile, in ethanol, in propanol, in butanol.

\begin{tabular}{|c|c|}
\hline \multicolumn{2}{|c|}{$\begin{array}{c}\text { TABLE-1 } \\
\text { THE OPTIMUM PARAMETERS ESTABLISHED FOR } \\
\text { AUTOMATIC BIAMPEROMETRIC TITRATION OF COPPER(II) } \\
\text { BY IODIDE IN NON-AQUEOUS MEDIA (METHANOL, } \\
\text { ETHANOL, PROPANOL, BUTANOL AND ACETONITRILE) } \\
\text { USING Pt (TWO WIRE) INDICATOR ELECTRODE. }\end{array}$} \\
\hline \multicolumn{2}{|c|}{ Optimum parameters } \\
\hline Indicator electrode & $\mathrm{Pt}$ (two wire) \\
\hline Non-aqueous solvents & $\begin{array}{l}\text { Ethanol, propanol, butanol and } \\
\text { acetonitrile }\end{array}$ \\
\hline Temperature of solution & $30^{\circ} \pm 1{ }^{\circ} \mathrm{C}$ \\
\hline Range of concentration & $\begin{array}{c}4 \times 10^{-5}-5 \times 10^{-3} \mathrm{~mol} \mathrm{~L}^{-1} \text { in acetonitrile } \\
1 \times 10^{-4}-5 \times 10^{-3} \mathrm{~mol} \mathrm{~L}^{-1} \text { in alcohols }\end{array}$ \\
\hline RSD & $4.2 \%$ \\
\hline Better end-point & $\begin{array}{l}\text { First end-point in acetonitrile and ethanol } \\
\text { Second end-point in butanol and propanol }\end{array}$ \\
\hline Volume of sample (mL) & 10 \\
\hline $\begin{array}{l}\text { Volume increment } \\
\text { (V. step), mL }\end{array}$ & $0.002-0.005$ \\
\hline Titr. Rate $\left(\mathrm{mL} \mathrm{min}{ }^{-1}\right)$ & $\max$ \\
\hline Signal drift (s) & off \\
\hline Equilibr. time (s) & 26 \\
\hline Start volume (start V) & off \\
\hline Filling rate $\left.(\mathrm{mL} \mathrm{min})^{-1}\right)$ & $\max$ \\
\hline Meas. impute & {$[\mathrm{U}(\mathrm{pol})]$} \\
\hline$\Delta \mathrm{E}:$ & \\
\hline In ethanol (mV) & 100 \\
\hline In propanol $(\mathrm{mV})$ & 300 \\
\hline In butanol (mV) & 300 \\
\hline In acetonitrile $(\mathrm{mV})$ & 100 \\
\hline
\end{tabular}

Analytical results: Concentrations of $\mathrm{Cu}^{2+}$ using automatic biamperometric titration by iodide in non-aqueous media (ethanol, propanol, butanol and acetonitrile) at Pt (two wire) indicator electrode were determined. It was found that, the results were better when the first end-point is used in acetonitrile and ethanol, while in butanol and propanol the use second end-point was better than use first end-point. The proposed method was successfully applied, for the first time, to the determination of $4 \times 10^{-5} \mathrm{~mol} \mathrm{~L}^{-1}$ copper(II) with RSD not more than $4.2 \%$ (Table-2).

\section{Conclusion}

Automatic biamperometric titration of copper(II) by iodide in non-aqueous media (methanol, ethanol, propanol, butanol and acetonitrile) was applied. In methanol did not appear quantify acceptable curves. In ethanol two end-points were observed, the first one according to the equation: $2 \mathrm{Cu}^{2+}+$ $4 \mathrm{I}^{-} \rightarrow 2 \mathrm{CuI} \downarrow+\mathrm{I}_{2}$ (1), while, the second-according to the following equation: $\mathrm{I}_{2}+\mathrm{I}^{-} \rightarrow \mathrm{I}_{3}^{-}$(2). In propanol and butanol two end-points were observed, the first one according to the equation: $2 \mathrm{Cu}^{2+}+2 \mathrm{I}^{-} \rightarrow 2 \mathrm{Cu}^{+}+\mathrm{I}_{2}(3)$ and the second-according to the following equation: $\mathrm{Cu}^{+}+\mathrm{I}^{-} \rightarrow \mathrm{CuI} \downarrow$ (4). Finally in acetonitrile two end-points were observed, the first one according to the eqn. (3) and the second according to the eqn. (2). It was found that, by using Pt electrode the redox couples $\mathrm{Cu}^{2+} / \mathrm{Cu}^{+}$and $\mathrm{I}_{2} / \mathrm{I}_{3}{ }^{-}$are reversible and the redox couple $\mathrm{Cu}^{+} / \mathrm{Cu}$ is irreversible. The proposed method was successfully applied, 


\begin{tabular}{|c|c|c|c|c|c|c|c|}
\hline & $\begin{array}{l}\text { AUTOMATIC BI } \\
\text { PROPANOL, }\end{array}$ & $\begin{array}{l}\text { MPER } \\
\text { UTANC }\end{array}$ & $\begin{array}{l}\text { ETRIC TITRAT } \\
\text { AND ACETONI }\end{array}$ & $\begin{array}{l}\text { ABLE-2 } \\
\text { J BY IODII } \\
\text { ILE) AT Pt }\end{array}$ & $\begin{array}{l}\text { NON-AQUEOU } \\
\text { WIRE) INDICA }\end{array}$ & $\begin{array}{l}\text { IA (ETHANOL, } \\
\text { LECTRODE }\end{array}$ & \\
\hline Solvent & $\begin{array}{c}\mathrm{x}_{\mathrm{i}}, \\
\mathrm{mmol} \mathrm{L}^{-1} \text { (taken) }\end{array}$ & $\begin{array}{l}\text { End- } \\
\text { point }\end{array}$ & $\begin{array}{l}\overline{\mathrm{X}} *, \mathrm{mmol} \mathrm{L}^{-1} \\
\text { (found) }\end{array}$ & $\begin{array}{c}\mathrm{SD} \\
\mathrm{mmol} \mathrm{L}^{-1}\end{array}$ & $\frac{\mathrm{SD}}{\sqrt{\mathrm{n}}}, \mathrm{mmol} \mathrm{L}^{-1}$ & $\bar{x} \pm \frac{\mathrm{t} . S \mathrm{D}}{\sqrt{\mathrm{n}}} \mathrm{mmol} \mathrm{L}^{-1}$ & $\begin{array}{l}\text { RSD } \\
(\%)\end{array}$ \\
\hline \multirow{20}{*}{ Ethanol } & 0.100 & I & 0.095 & 0.005 & 0.0022 & $0.095 \pm 0.0061$ & 5.0 \\
\hline & & II & - & - & - & - & - \\
\hline & 0.200 & I & 0.198 & 0.010 & 0.0045 & $0.198 \pm 0.012$ & 4.8 \\
\hline & & II & - & - & - & - & - \\
\hline & 0.400 & I & 0.401 & 0.018 & 0.0080 & $0.401 \pm 0.022$ & 4.6 \\
\hline & & II & - & - & - & - & - \\
\hline & 0.600 & I & 0.602 & 0.026 & 0.012 & $0.602 \pm 0.033$ & 4.4 \\
\hline & & II & - & - & - & - & - \\
\hline & 0.800 & I & 0.802 & 0.038 & 0.017 & $0.802 \pm 0.047$ & 4.2 \\
\hline & & II & 0.791 & 0.027 & 0.012 & $0.791 \pm 0.033$ & 4.8 \\
\hline & 1.00 & I & 1.00 & 0.039 & 0.017 & $1.00 \pm 0.048$ & 3.9 \\
\hline & & II & 0.99 & 0.046 & 0.021 & $0.99 \pm 0.057$ & 4.6 \\
\hline & 2.00 & I & 1.99 & 0.078 & 0.035 & $1.99 \pm 0.097$ & 3.7 \\
\hline & & II & 1.97 & 0.088 & 0.039 & $1.97 \pm 0.109$ & 4.4 \\
\hline & 3.00 & I & 3.02 & 0.105 & 0.047 & $3.02 \pm 0.130$ & 3.5 \\
\hline & & II & 2.99 & 0.132 & 0.059 & $2.99 \pm 0.164$ & 4.4 \\
\hline & 4.00 & I & 4.05 & 0.14 & 0.063 & $4.05 \pm 0.174$ & 3.6 \\
\hline & & II & 3.96 & 0.18 & 0.080 & $3.96 \pm 0.223$ & 4.6 \\
\hline & 5.00 & I & 4.98 & 0.18 & 0.080 & $4.98 \pm 0.223$ & 3.7 \\
\hline & & II & 4.90 & 0.24 & 0.107 & $4.90 \pm 0.298$ & 4.8 \\
\hline \multirow{20}{*}{ Propanol } & 0.100 & $\mathrm{I}$ & - & - & - & - & - \\
\hline & & II & 0.096 & 0.004 & 0.0018 & $0.096 \pm 0.005$ & 3.8 \\
\hline & 0.200 & I & - & - & - & - & - \\
\hline & & II & 0.198 & 0.008 & 0.0036 & $0.198 \pm 0.01$ & 3.8 \\
\hline & 0.400 & I & - & - & - & - & - \\
\hline & & II & 0.401 & 0.015 & 0.007 & $0.401 \pm 0.019$ & 3.7 \\
\hline & 0.600 & I & 0.592 & 0.029 & 0.013 & $0.592 \pm 0.036$ & 4.9 \\
\hline & & II & 0.600 & 0.022 & 0.01 & $0.600 \pm 0.028$ & 3.6 \\
\hline & 0.800 & I & 0.790 & 0.038 & 0.017 & $0.790 \pm 0.047$ & 4.8 \\
\hline & & II & 0.803 & 0.027 & 0.012 & $0.803 \pm 0.033$ & 3.4 \\
\hline & 1.00 & I & 0.994 & 0.046 & 0.020 & $0.994 \pm 0.055$ & 4.6 \\
\hline & & II & 1.01 & 0.031 & 0.014 & $1.01 \pm 0.039$ & 3.1 \\
\hline & 2.00 & I & 1.99 & 0.088 & 0.039 & $1.99 \pm 0.110$ & 4.4 \\
\hline & & II & 2.00 & 0.056 & 0.025 & $2.00 \pm 0.069$ & 2.8 \\
\hline & 3.00 & I & 2.98 & 0.131 & 0.059 & $2.98 \pm 0.162$ & 4.4 \\
\hline & & II & 3.01 & 0.080 & 0.036 & $3.01 \pm 0.101$ & 2.7 \\
\hline & 4.00 & I & 3.97 & 0.18 & 0.080 & $3.97 \pm 0.222$ & 4.5 \\
\hline & & II & 4.02 & 0.11 & 0.049 & $4.02 \pm 0.136$ & 2.8 \\
\hline & 5.00 & I & 4.98 & 0.23 & 0.103 & $4.98 \pm 0.286$ & 4.6 \\
\hline & & II & 5.04 & 0.15 & 0.067 & $5.04 \pm 0.186$ & 3.0 \\
\hline \multirow{19}{*}{ Butanol } & 0.080 & $\mathrm{I}$ & - & - & - & - & - \\
\hline & & II & 0.078 & 0.0035 & 0.0016 & $0.078 \pm 0.0044$ & 4.5 \\
\hline & 0.100 & I & - & - & - & - & - \\
\hline & & II & 0.098 & 0.0033 & 0.0015 & $0.098 \pm 0.0042$ & 3.4 \\
\hline & 0.200 & I & - & - & - & - & - \\
\hline & & II & 0.201 & 0.007 & 0.0031 & $0.201 \pm 0.0086$ & 3.3 \\
\hline & 0.400 & I & 0.386 & 0.018 & 0.0080 & $0.386 \pm 0.022$ & 4.8 \\
\hline & & II & 0.404 & 0.013 & 0.0058 & $0.404 \pm 0.016$ & 3.2 \\
\hline & 0.600 & I & 0.597 & 0.027 & 0.012 & $0.597 \pm 0.033$ & 4.6 \\
\hline & & II & 0.602 & 0.019 & 0.0085 & $0.602 \pm 0.023$ & 3.2 \\
\hline & 0.800 & I & 0.793 & 0.036 & 0.016 & $0.793 \pm 0.045$ & 4.5 \\
\hline & & II & 0.801 & 0.025 & 0.011 & $0.801 \pm 0.030$ & 3.1 \\
\hline & 1.00 & I & 0.997 & 0.043 & 0.019 & $0.997 \pm 0.053$ & 4.3 \\
\hline & & II & 1.02 & 0.029 & 0.013 & $1.02 \pm 0.036$ & 2.9 \\
\hline & 2.00 & I & 1.99 & 0.085 & 0.038 & $1.99 \pm 0.105$ & 4.3 \\
\hline & & II & 2.02 & 0.054 & 0.024 & $2.02 \pm 0.067$ & 2.7 \\
\hline & 3.00 & I & 2.99 & 0.129 & 0.057 & $2.99 \pm 0.160$ & 4.3 \\
\hline & & II & 3.02 & 0.079 & 0.035 & $3.02 \pm 0.0 .097$ & 2.6 \\
\hline & 4.00 & I & 3.98 & 0.18 & 0.080 & $3.98 \pm 0.222$ & 4.4 \\
\hline
\end{tabular}




\begin{tabular}{|c|c|c|c|c|c|c|c|}
\hline Solvent & $\begin{array}{c}\mathrm{X}_{\mathrm{i}}, \\
\mathrm{mmol} \mathrm{L}^{-1}(\text { taken })\end{array}$ & $\begin{array}{l}\text { End- } \\
\text { point }\end{array}$ & $\begin{array}{c}\overline{\mathrm{X}} *, \text { mmol L } \\
\text { (found) }\end{array}$ & $\begin{array}{c}\mathrm{SD} \\
\mathrm{mmol} \mathrm{L}^{-1}\end{array}$ & $\frac{\mathrm{SD}}{\sqrt{\mathrm{n}}}, \mathrm{mmol} \mathrm{L}^{-1}$ & $\overline{\mathrm{x}} \pm \frac{\mathrm{t} . \mathrm{SD}}{\sqrt{\mathrm{n}}} \mathrm{mmol} \mathrm{L} \mathrm{L}^{-1}$ & $\begin{array}{l}\mathrm{RSD} \\
(\%)\end{array}$ \\
\hline & & II & 4.00 & 0.11 & 0.049 & $4.00 \pm 0.136$ & 2.7 \\
\hline & & II & 5.01 & 0.14 & 0.063 & $5.01 \pm 0.174$ & 2.9 \\
\hline \multirow{24}{*}{ Acetonitrile } & 0.040 & $\mathrm{I}$ & 0.039 & 0.0017 & 0.0008 & $0.039 \pm 0.0022$ & 4.2 \\
\hline & & II & 0.040 & 0.0018 & 0.0008 & $0.040 \pm 0.0022$ & 4.5 \\
\hline & & II & 0.049 & 0.0021 & 0.0009 & $0.049 \pm 0.0025$ & 4.2 \\
\hline & 0.060 & I & 0.062 & 0.0021 & 0.0009 & $0.062 \pm 0.0025$ & 3.4 \\
\hline & & II & 0.058 & 0.0024 & 0.0011 & $0.058 \pm 0.0030$ & 4.1 \\
\hline & 0.080 & I & 0.081 & 0.0028 & 0.0012 & $0.081 \pm 0.0033$ & 3.2 \\
\hline & & II & 0.079 & 0.0032 & 0.0014 & $0.079 \pm 0.0040$ & 4.0 \\
\hline & 0.100 & I & 0.099 & 0.0030 & 0.0013 & $0.099 \pm 0.0036$ & 3.1 \\
\hline & & II & 0.098 & 0.004 & 0.0018 & $0.098 \pm 0.0050$ & 3.9 \\
\hline & & II & 0.193 & 0.008 & 0.0036 & $0.193 \pm 0.010$ & 3.8 \\
\hline & 0.400 & I & 0.402 & 0.011 & 0.0049 & $0.402 \pm 0.014$ & 2.8 \\
\hline & & II & 0.397 & 0.015 & 0.0067 & $0.397 \pm 0.018$ & 3.7 \\
\hline & 0.600 & I & 0.603 & 0.016 & 0.0071 & $0.603 \pm 0.02$ & 2.7 \\
\hline & & II & 0.595 & 0.021 & 0.0094 & $0.595 \pm 0.026$ & 3.5 \\
\hline & 0.800 & I & 0.800 & 0.020 & 0.0089 & $0.800 \pm 0.025$ & 2.5 \\
\hline & & II & 0.799 & 0.026 & 0.012 & $0.799 \pm 0.033$ & 3.2 \\
\hline & 1.00 & I & 1.00 & 0.024 & 0.011 & $1.00 \pm 0.030$ & 2.4 \\
\hline & & II & 1.00 & 0.029 & 0.013 & $1.00 \pm 0.036$ & 2.9 \\
\hline & 2.00 & I & 2.01 & 0.048 & 0.021 & $2.01 \pm 0.058$ & 2.4 \\
\hline & & II & 1.99 & 0.048 & 0.021 & $1.99 \pm 0.058$ & 2.4 \\
\hline & 3.00 & I & 3.00 & 0.072 & 0.032 & $3.00 \pm 0.089$ & 2.4 \\
\hline & & II & 3.00 & 0.075 & 0.034 & $3.00 \pm 0.093$ & 2.5 \\
\hline & 4.00 & I & 4.00 & 0.10 & 0.045 & $4.00 \pm 0.125$ & 2.5 \\
\hline & & II & 4.98 & 0.14 & 0.063 & $4.98 \pm 0.175$ & 2.8 \\
\hline
\end{tabular}

for the determination of $4 \times 10^{-5} \mathrm{~mol} \mathrm{~L}^{-1}$ copper(II) with RSD not more than $4.2 \%$.

\section{REFERENCES}

1. J.J. Lingane, Electroanalytical Chemistry, Lntersciences, New York, edn 2, Chapter 12 (1958)

2. H.L. Kies and H. Ligtenberg, Z. Anal. Chem., 287, 142 (1977).

3. Z. Marczenko and T. Kowalski, Anal. Chim. Acta, 96, 415 (1978).

4. M. Trojanowicz and J. Michalowski, J. Flow Injection Anal., 11, 34 (1994).

5. B. Velikov and J. Dolezal, Anal. Chim. Acta, 93, 161 (1977).

6. J. Komljenovic, V. Martinacand and N. Radic, Anal. Chim. Acta, 231, 137 (1990)

7. V.K. Gupta, A.K. Jain, G. Maheshwari, H. Lang and Z. Ishtaiwi, Sens. Actuators B, 117, 99 (2006).

8. I. Szilágyi, I. Labádi, K. Hernadi, I. Pálinkó, N.V. Nagy, L. Korecz, A. Rockenbauer, Z. Kele and T. Kiss, J. Inorg. Biochem., 99, 1619 (2005).

9. V.A. Isaeva, ZH.F. Gesse and V.A. Sharnin, J. Coord. Chem., 32, 340 (2006)

10. V.K. Gupta, R. Prasad and A. Kumar, Talanta, 60, 149 (2003).

11. R. Mihajlovic, Z. Stanic and M. Antonijevic, Electrochim. Acta, 51, 3707 (2006)
12. A.A. Ramadan, M.A. Hourieh and P. Labat, Res. J. Aleppo. Univ., 14, 185 (1992).

13. M. Dahhan, Ph.D. Thesis, Potentiometric Titration of Copper(II) in Acetone Solution, Aleppo University, Aleppo, Syria (2009).

14. A.A. Ramadan, H. Mandil and M. Dahhan, Res. J. Aleppo Univ., 60, 347 (2008).

15. P. Labat, Ph.D. Thesis, Electrochemical Analysis of Some Toxic Pollutants, Aleppo University, Aleppo, Syria (1992).

16. G. Sabagh, M.Sc. Thesis, Determination of Pollutants by Copper, Lead and Nitrate Using Ion Selective Electrodes, Aleppo University, Aleppo, Syria (1994).

17. A.A. Ramadan and G. Sabagh, Res. J. Aleppo Univ., 14, 87 (1992).

18. A.A. Ramadan and G. Sabagh, Res. J. Aleppo Univ., 17, 93 (1994).

19. G. Edrees, M.Sc. Thesis, High Frequency Titration of Halogens in NonAqueous Media, Aleppo University, Aleppo, Syria (2005).

20. A.A. Ramadan, A. Al-Ahmad and G. Edrees, Res. J. Aleppo Univ., 45, 95 (2005).

21. A.A. Ramadan, P.K. Agasayan and S.I. Petrov, Gen. Chem., 44, 1144 (1974).

22. A.A. Ramadan, P.K. Agasayan and S.I. Petrov, Gen. Chem., 44, 2299 (1974).

23. A.A. Ramadan, P.K. Agasayan and S.I. Petrov, Zh. Anal. Khim., 28, 2396 (1973).

24. A.A. Ramadan, P.K. Agasayan and S.I. Petrov, Zh. Anal. Khim., 29, 544 (1974). 